\title{
Karakterisasi Bahan Anti Browning dari Ekstrak Air Buah Jambu Batu (Psidium guajava Linn) pada Buah Apel Malang (Malus sylvestris (L.) Mill)
}

\section{Anti-Browning Material Characterization of The Water Extract of Guava Fruit (Psidium guajava Linn) in Malang Apples (Malus sylvestris (L.) Mill)}

\author{
Oktarina Husaini", Zulkifli, Martha L. Lande, dan E.Nurcahyani \\ Jurusan Biologi - FMIPA Universitas Lampung - Bandar Lampung \\ Jl. Prof. Dr Sumantribrojonegoro No.1. Bandar Lampung,35145 \\ Email : Oktarinahusaini23@gmail.com
}

\begin{abstract}
The purpose of this study was to prove that the water extract of guava pulp can hinder the process of browning in apples Malang. The research was conducted in October - November 2016 in the Laboratory of Plant Physiology, Department of Biology, Faculty of Mathematics and Natural Sciences, University of Lampung. This study uses a completely randomized design $(C R D)$ with 6 degree of concentration of water extract of the fruit flesh guava: control (Citric acid $2 \% \mathrm{w} / \mathrm{v}), 0 \% \mathrm{v} / \mathrm{v}, 25 \% \mathrm{v} / \mathrm{v}, 50 \% \mathrm{v} / \mathrm{v}, 75 \% \mathrm{v} / \mathrm{v}, 100 \% \mathrm{v} / \mathrm{v}$. Browning index is determined based on the absorbance of the extract of apple Malang at a wavelength of $420 \mathrm{~nm}$. Total soluble carbohydrate content was determined by the phenol-sulfuric method, while estimating dehydrogenase enzyme activity by methylene blue method. Levene's test for homogeneity, analysis of variance and LSD test was carried out at 5\% significance level. Water extract of guava fruit has the same effectiveness with citric acid $2 \% \mathrm{w} / \mathrm{v}$ in inhibiting browning apples Malang. Similarly, the water extract of guava fruit as well as citric acid $2 \% \mathrm{w} / \mathrm{v}$ has the same effect on total soluble carbohydrate content and the activity of the enzyme dehydrogenase. Water extract of guava fruit has the same effectiveness with citric acid $2 \% \mathrm{w} / \mathrm{v}$ except for $100 \%$ concentration on reducing sugar level. The final conclusion is that the water extract of guava fruit has the different characteristics as citric acid 2\% w/v in inhibiting browning in apples Malang.
\end{abstract}

Keywords: water extract of guava fruit, browning index, total soluble carbohydrate content, dehydrogenase enzyme activity.

Diterima : 21 Desember 2016, Disetujui : 18 Juli 2017

\section{PENDAHULUAN}

Apel (Malus sylvestris (L.) Mill) adalah tanaman yang berasal dari daerah Asia Barat. Tanaman ini hidup pada daerah beriklim subtropis dengan temperatur atau kondisi udara yang dingin. Di Indonesia apel mulai dibudidayakan sejak tahun 1934 hingga saat ini. Salah satu wilayah di Indonesia yaitu kota malang yang menghasilkan banyak buah apel. Kota Malang memiliki iklim yang sangat cocok untuk penanaman dan pembudidaya buah apel. Buah Apel merupakan buah yang tergolong populer di seluruh dunia karena mempunyai rasa yang sangat menyegarkan. Buah apel memiliki nilai penting dalam segi ekonomi dan mempunyai kandungan gizi yang baik untuk kesehatan (Soelarso, 1997). 
Permasalahan yang sering terjadi selama penyimpanan buah apel pada jangka waktu yang lama yaitu daging buah apel akan berubah menjadi warna kecoklatan (Browning). Hal ini dapat menyebabkan kerugian ekonomi. Daging buah apel mengalami perubahan warna menjadi coklat melalui oksidasi enzimatik senyawa fenolik primer selama masa penyimpanan tersebut. Perubahan warna pada buah apel ini dapat terjadi karena ketidakseimbangan antara proses oksidatif dan reduktif metabolisme dalam buah yang menyebabkan oksigen menjadi reaktif. Hal ini dapat menyebabkan hilangnya tekstur dan rasa pada buah yang mengalami browning (Christin et al, 2007).

Pencoklatan (Browning) merupakan perubahan kecoklatan pada buah yang terjadi akibat proses enzimatik oleh polifenol oksidasi. Secara umum perubahan browning sering terjadi pada buah-buahan seperti pisang, pear, salak, pala, dan apel. Perubahan browning ini terbagi menjadi dua yaitu secara enzimatik dan secara non enzimatik. Sayur dan buah dapat mengalami browning jika terkelupas atau dipotong. Browning ini merupakan proses pembentukan pigmen berwarna kuning yang akan segera berubah menjadi coklat gelap (Rachmawan, 2001).

Pencegahan browning telah banyak dilakukan dengan menggunakan penambahan bahan-bahan kimia sintetis seperti bisulfid, asam sitrat, asam askorbat, asam benzoat dan kalsium klorida sebagai senyawa anti browning pada berbagai jenis buah-buahan dan sayur-sayuran. Namun, pengunaan bahan kimia sintetis sebagai anti browning telah dilarang karena dapat menyebabkan asmatik dan efek samping bagi kesehatan pada konsumen. Pengunaan bahan - bahan alami lebih efektif dalam mencegah browning pada buah-buahan dan sayur-sayuran dibanding bahan kimia sintetis (Sappers and Miller, 1992).

Berdasarkan penelitian Thipnate dan Sukhonthara (2015) buah jambu batu mempunyai nilai polifenol dan kapasitas antioksidan yang tinggi sehingga dapat digunakan sebagai bahan alami pencegah browning pada buah apel. Buah jambu batu juga mengandung metabolit sekunder yang merupakan inhibitor dari enzim Polifenol Oksidase (PPO) penyebab browning pada buah-buahan.

Dalam makalah ini peneliti melaporkan pengaruh ekstrak air buah jambu batu (Psidium guajava Linn.) terhadap indeks browning, kandungan karbohidrat terlarut total, aktivitas enzim dehidrogenase dan level gula pereduksi.

\section{METODE PENELITIAN}

Penelitian ini telah dilaksanakan di Laboratorium Fisiologi Tumbuhan Jurusan Biologi, Fakultas Matematika dan Ilmu Pengetahuan Alam, Universitas Lampung pada bulan Oktober - November 2016. Rancangan percobaan yang digunakan menggunakan Rancangan acak lengkap (RAL) dengan ekstrak buah jambu batu sebagai faktor utama yang terdiri dari 6 taraf konsentrasi : $\mathrm{K}_{0}$ sebagai kontrol (air) 0\% v/v, $\mathrm{K}_{1}$ (asam sitrat $2 \% \mathrm{~b} / \mathrm{v}$ ), $\mathrm{K}_{2} 25 \% \mathrm{v} / \mathrm{v}, \mathrm{K}_{3} 50 \% \mathrm{v} / \mathrm{v}, \mathrm{K}_{4} 75 \% \mathrm{v} / \mathrm{v}$, dan $\mathrm{K}_{5} 100 \%$ v/v setiap perlakuan diulang 5 kali sehingga jumlah satuan percobaan seluruhnya 30 potongan buah apel. Variabel dalam penelitian ini adalah indeks browning, kandungan karbohidrat terlarut total, level gula pereduksi, dan aktivitas enzim dehidrogenase. Sedangkan parameter kuantitatif dalam penelitian ini adalah indeks browning, kandungan karbohidrat terlarut total, dan aktivitas enzim dehidrogenase sedangkan parameter kualitatif adalah gula pereduksi.

Langkah pertama adalah pembuatan ekstrak daging buah jambu batu dibuat berdasarkan penelitian Thipnate dan Sukhonthara (2015) 25\% ekstrak daging buah jambu batu setara dengan 0,24 g basah daging buah jambu batu dalam $1 \mathrm{ml}$ aquades. Untuk merendam 5 potongan buah apel Malang dibutuhkan $500 \mathrm{ml}$ ekstrak buah jambu batu.

Langkah kedua adalah pemberian perlakuan $500 \mathrm{ml}$ ekstrak air buah jambu batu dengan konsentrasi masing masing $0 \% \mathrm{v} / \mathrm{v}$ (air), 25\% v/v, $50 \% \mathrm{v} / \mathrm{v}, 75 \% \mathrm{v} / \mathrm{v}$, dan $100 \% \mathrm{v} / \mathrm{v}$ dan $500 \mathrm{ml}$ asam sitrat $2 \% \mathrm{~b} / \mathrm{v}$ disiapkan dalam beaker gelas. 5 potongan buah apel yang dipilih secara acak dimasukan ke dalam masing 
masing beaker gelas dan dibiarkan selama 15 menit. Selanjutnya potongan buah apel tersebut ditaruh dicawan petri yang telah diberi label perlakuan dan ulangan kemudian inkubasi selama 72 jam.

Langkah ketiga adalah pengamatan parameter indeks browning menurut Jeong et al., (2008). 1 gram daging buah apel digerus sampai halus dalam mortar dan ditambakan $10 \mathrm{ml}$ aquadest. Ekstrak disaring kedalam erlenmayer dengan kertas saring Whatman no.1. Absorbansi diukur pada panjang gelombang $420 \mathrm{~nm}$. Pengamatan kandungan karbohidrat terlarut total ditentukan berdasarkan metode fenol sulfur dengan cara menimbang $100 \mathrm{mg}$ daging buah apel digerus sampai halus dalam mortar dan diekstrak dengan $100 \mathrm{ml}$ aquadest. Ekstrak disaring kedalam erlenmayer dengan kertas saring Whatman no.1.2 ml ekstrak dimasukkan kedalam tabung reaksi dan ditambahkan $2 \mathrm{ml}$ larutan $\mathrm{H}_{2} \mathrm{SO}_{4}$ pekat dan $1 \mathrm{ml}$ larutan fenol.Ekstrak dibiarkan beberapa saat sampai berwarna cokelat kemerahan menunjukkan karbohidrat terlarut. Absorbansi diukur dengan spektrofotometer UV dengan panjang gelombang $490 \mathrm{~nm}$.

Kandungan karbohidrat ditentukan berdasarkan kurva standar glukosa dan dinyatakan dalam satuan $\mathrm{mg}$ jaringan. Pengamatan gula pereduksi dideteksi dengan uji benedict. Daging buah apel sebanyak 1 gram ditimbang. Daging buah apel ditumbuk halus dalam mortar dan ditambahkan $5 \mathrm{ml}$ aquadest. Ekstrak disaring dengan menggunakan kertas saring Whatman no.1 kedalam tabung reaksi. Kemudian ditambahkan $3 \mathrm{ml}$ benedict dan dipananskan selama 10 menit. Endapan warna merah bata yang terbentuk menunjukkan adanya gula pereduksi.

Pengamatan aktifitas enzim dehidroginase diukur berdasarkan metilen blue (Witham et al.,1986). Daging buah apel dipotong berukuran $1 \times 1 \times 1 \mathrm{~cm}$ dan ditimbang sebanyak 1 gram kemudian ditaruh ke dalam tabung reaksi dan ditambahkan methylen blue $0,025 \%$ lalu ditutup rapat dengan plastik dan diikat menggunakan karet gelang, diiinkubasi selama 24 jam. Perubahan warna ditentukan berdasarkan transmisi larutan pada panjang gelombang $600 \mathrm{~nm}$. Sebagai kontrol, daging buah apel yang telah dinonaktifkan enzim dehidroginasenya dengan cara perendaman dalam air panas selama 20 menit. Aktifitas enzim dehidroginase ditunjukkan oleh transmisi larutan methylen blue. Semakin besar transmisi dan semakin bening larutan, maka semakin tinggi aktifitas enzim dehidroginase.

Langkah keempat adalah homogenitas ragam ditentukan berdasarkan uji Levene pada taraf nyata $5 \%$. Data indeks browning, Kandungan karbohidrat terlarut total, aktivitas enzim dehidroginase dianalisis ragam pada taraf nyata $5 \%$ dan dilanjutkan dengan uji BNT pada taraf nyata $5 \%$.

\section{HASIL DAN PEMBAHASAN}

Warna Permukaan Daging Buah. Perbedaan warna permukaan daging buah apel Malang yang direndam dalam air dan asam sitrat $2 \% \mathrm{~b} / \mathrm{v}$ ditunjukan pada Gambar 1.

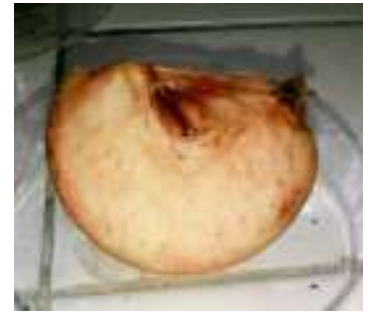

Air

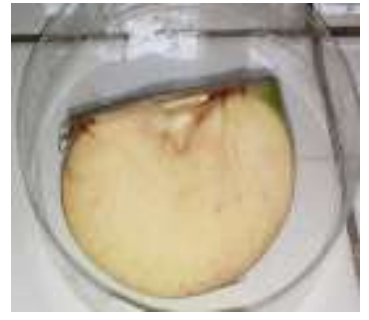

Asam sitrat $2 \% \mathrm{~b} / \mathrm{v}$

Gambar 1. Warna permukaan daging buah apel Malang setelah 72 jam dalam air dan asam sitrat $2 \% \mathrm{~b} / \mathrm{v}$.

Dari hasil pengamatan terlihat bahwa permukaan daging buah apel Malang yang direndam air berwarna coklat sedangkan buah apel Malang yang direndam asam sitrat $2 \% \mathrm{~b} / \mathrm{v}$ relatif masih berwarna putih.Hal ini menunjukan bahwa pada buah apelyang direndam air terjadi browning sedangkan yang direndam asam sitrat $2 \% \mathrm{~b} / \mathrm{v}$ tidak terjadi browning. 
Perbedaan warna permukaan daging buah apel malang yang direndam dalam asam sitrat dengan buah apel malang yang direndam dengan ekstrak daging buah jambu batu ditunjukan pada Gambar 2.


Ekstrak jambu batu $75 \% \mathrm{v} / \mathrm{v}$

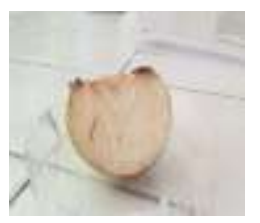

Ekstrak jambu batu $25 \% \mathrm{v} / \mathrm{v}$

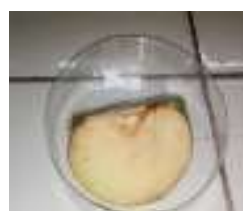

Ekstrak jambu batu $50 \% \mathrm{v} / \mathrm{v}$

Gambar 2. Warna permukaan daging buah apel malang setelah 72 jam dalam asam sitrat $2 \% \mathrm{~b} / \mathrm{v}$ dan ekstrak air buah jambu batu.

Indeks Browning. Hasil uji t pada taraf nyata 5\% menunjukan bahwa indeks browning buah apel malang yang direndam dalam asam sitrat $2 \% \mathrm{~b} / \mathrm{v}(0,667 \pm 0,006)$ berbeda nyata dari indeks browning buah apel malang yang direndam dalam air $(0,792 \pm 0,004)$. Indeks browning buah apel malang yang direndam dengan asam sitrat $2 \% \mathrm{~b} / \mathrm{v}$ lebih rendah dibandingkan dengan indeks browning buah apel malang yang direndam dengan air. Hubungan konsentrasi ekstrak air buah jambu batu dengan indeks browning buah apel malang ditunjukkan pada Gambar 3.

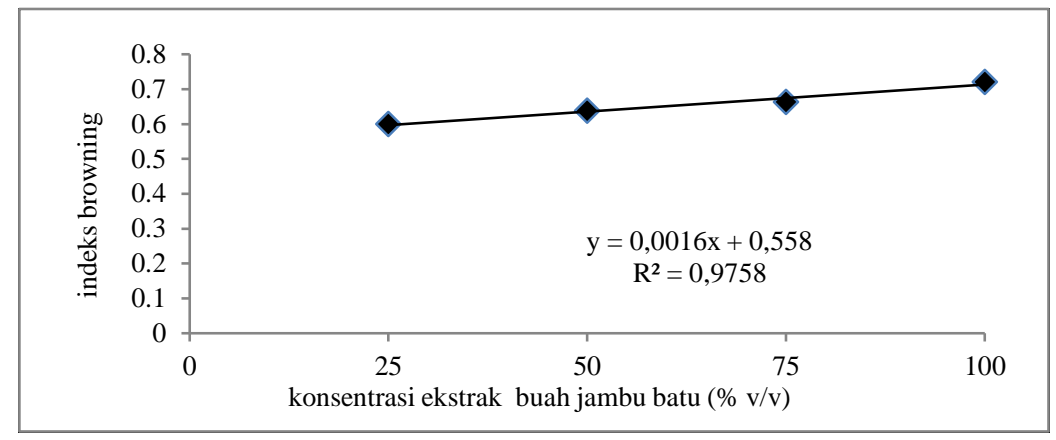

Gambar 3. Kurva hubungan antara konsentrasi ekstrak buah jambu batu dengan indeks Browning buah apel malang

Dari kurva terlihat bahwa hubungan antara konsentrasi ekstrak air buah jambu batu dengan indeks browning buah apel malang adalah Linier positif dengan persamaan $\mathrm{y}=0,0016 \mathrm{x}+0,558$ dan $\mathrm{R}^{2}=$ 0,9758.Koefisien korelasi indeks browning adalah sebesar 0,98. Hal ini menunjukan bahwa hubungan antara konsentrasi ekstrak air buah jambu batu sangat kuat dengan indeks browningbuah apel malang.

Perendaman daging buah apel malang dalam ekstrak buah jambu batu selama 15 menit pada konsentrasi $25 \% \mathrm{v} / \mathrm{v}, 50 \% \mathrm{v} / \mathrm{v}$, dan $75 \% \mathrm{v} / \mathrm{v}$ menurunkan indeks browning buah apel malang dibandingkan perendaman daging buah apel malang dalam larutan asam sitrat $2 \% \mathrm{~b} / \mathrm{v}$. Namun pada perendaman daging buah apel malang dalam ekstrak air buah jambu batu dengan konsentrasi 100\% v/v menunjukan sedikit browning.

Besarnya penurunannya indeks browning pada buah apel malang sangat bergantung pada konsentrasi ekstrak air buah jambu batu yang digunakan, namun konsentrasi yang terlalu tinggi dapat menyebabkan 
browning pada buah apel malang. Oleh sebab itu perendaman ekstrak air buah jambu batu pada konsentrasi $25 \% \mathrm{v} / \mathrm{v}, 50 \% \mathrm{v} / \mathrm{v}$, dan $75 \% \mathrm{v} / \mathrm{v}$ menurunkan $\mathrm{pH}$ jaringan sehingga menonaktifkan enzim polifenol aksidase (PPO) sedangkan perendaman ekstrak air buah jambu batu pada konsentrasi $100 \% \mathrm{v} / \mathrm{v}$ sedikit menurunkan $\mathrm{pH}$ jaringan karena pada konsentrasi $100 \%$ v/v buah apel malang mengalami sedikit browning.

Kandungan Karbohidrat Terlarut Total. Hasil uji t pada taraf nyata 5\% (Lampiran 2) menunjukan bahwa kandungan karbohidrat terlarut total buah apel malang yang direndam dalam asam sitrat $(27,130 \pm 1,438)$ berbeda nyata dibanding buah apel malang yang direndam dalam air $(28,318 \pm 5,255)$. Kandungan karbohidrat terlarut total buah apel malang yang direndam dengan asam sitrat lebih rendah dibandingkan dengan buah apel malang yang direndam dengan air. Hubungan antara konsentrasi ekstrak air buah jambu batu dengan Kandungan karbohidrat terlarut totalbuah apel malang ditunjukkan pada Gambar 4.

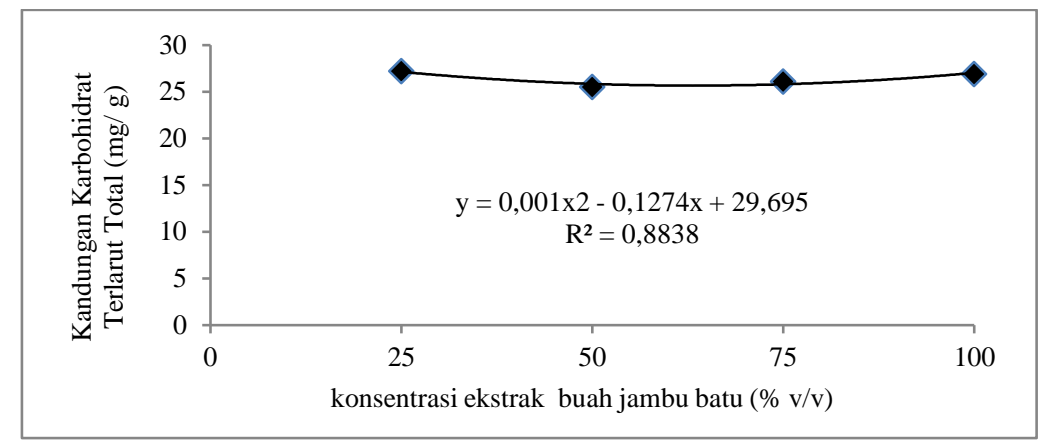

Gambar 4. Kurva hubungan antara konsentrasi ekstrak buah jambu batu dengan kandungan karbohidrat terlarut total buah apel malang.

Dari kurva terlihat bahwa hubungan antara konsentrasi ekstrak air buah jambu batu dengan kandungan karbohidrat terlarut total buah apel malang adalah kuadratik dengan persamaan $y=0,001 x^{2}-0,1274 x+$ 29,695 danR $^{2}=0,8838$. Koefisien korelasi kandungan karbohidrat terlarut total adalah sebesar 0,94. Hal ini menunjukan bahwa hubungan antara konsentrasi ekstrak air buah jambu batu sangat kuat dengan kandungan karbohidrat terlarut total buah apel malang. Konsentrasi minimum kandungan karbohidrat terlarut total yaitu terdapat pada konsentrasi 63,7\%. Kandungan karbohidrat terlarut total buah apel malang cenderung mengalami penurunan dengan meningkatnya konsentrasi ekstrak air buah jambu batu yaitu sebesar $94 \%$ untuk setiap peningkatan konsentrasi ekstrak air buah jambu batu.

Kandungan karbohidrat terlarut total buah apel malang yang direndam larutan asam sitrat $2 \% \mathrm{~b} / \mathrm{v}$ lebih rendah dibandingkan kandungan karbohidrat terlarut total buah apel malang yang direndam dengan air sedangkan kandungan karbohidrat terlarut total buah apel malang yang direndam dengan ekstrak air buah jambu batu cenderung mengalami penurunan dengan meningkatnya konsentrasi ekstrak air buah jambu batu.

Aktivitas Enzim Dehidrogenase. Hasil uji t pada taraf nyata 5\% (Lampiran 3) menunjukan bahwa aktivitas enzim dehidrogenase buah apel malang yang direndam dalam asam sitrat $2 \% \mathrm{~b} / \mathrm{v}(0,046764 \pm 1,63 \mathrm{E}-$ 05) berbeda nyata dibandingkan dengan buah apel malang yang direndam dalam air $(0,04198 \pm 4,094 \mathrm{E}-07)$. Aktivitas enzim dehidrogenase buah apel malang yang direndam dengan asam sitrat lebih rendah dibandingkan dengan buah apel malang yang direndam dengan air. Hubungan antara konsentrasi ekstrak air buah jambu batu dengan aktivitas enzim dehidrogenasebuah apel malang ditunjukkan pada gambar 5 . 


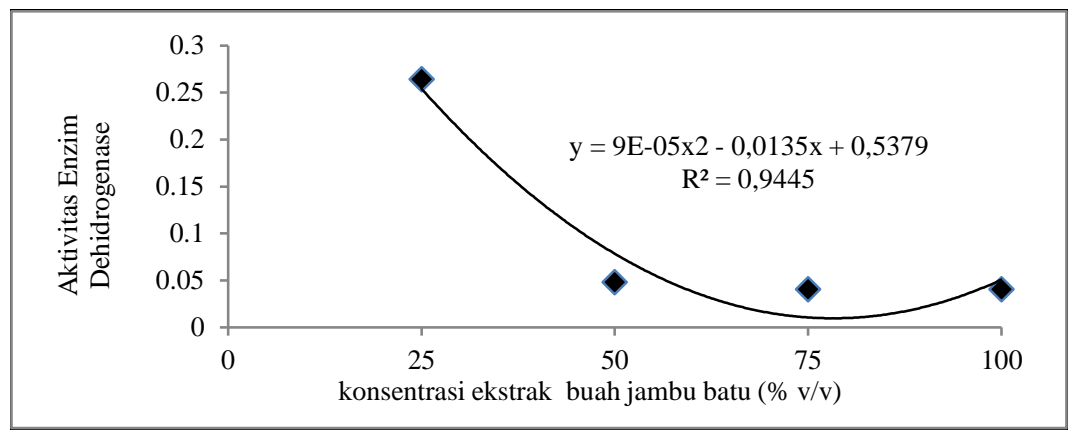

Gambar 5. Kurva hubungan antara konsentrasi ekstrak buah jambu batu dengan aktivitas enzim dehidrogenase buah apel malang.

Dari kurva terlihat bahwa hubungan antara konsentrasi ekstrak air buah jambu batu dengan aktivitas enzim dehidrogenase buah apel malang adalah kuadratik dengan persamaan $y=9 \mathrm{E}-05 \mathrm{x}^{2}-0,0135 \mathrm{x}+0,5379$ dan $R^{2}=0,9445$. Koefisien korelasi aktivitas enzim dehidrogenase adalah sebesar 0,971 . Hal ini menunjukan bahwa hubungan antara konsentrasi ekstrak air buah jambu batu sangat kuat dengan aktivitas enzim dehidrogenase buah apel malang. Konsentrasi minimum aktivitas enzim dehidrogenase yaitu terdapat pada konsentrasi $75 \%$. Aktivitas enzim dehidrogenase buah apel malang cenderung mengalami penurunan dengan meningkatnya konsentrasi ekstrak air buah jambu batu yaitu sebesar $68 \%$ untuk setiap peningkatan konsentrasi ekstrak air buah jambu batu.

Aktivitas enzim dehidrogenase pada buah apel malang yang direndam larutan asam sitrat $2 \% \mathrm{~b} / \mathrm{v}$ lebih rendah dibandingkan aktivitas enzim dehidrogenase buah apel malang yang direndam dengan air sedangkan aktivitas enzim dehidrogenase buah apel malang yang direndam dengan ekstrak air buah jambu batu cenderung mengalami penurunan dengan meningkatnya konsentrasi ekstrak air buah jambu batu.

Level Gula Pereduksi. Pengaruh ekstrak air buah jambu batu terhadap level gula pereduksi pada buah apel malang ditunjukan pada tabel 1 .

Tabel 1. Level gula pereduksi

\begin{tabular}{cc}
\hline Konsentrasi ekstrak air buah jambu batu (\%v/v) & Level Gula Pereduksi \\
\hline Kontrol(Air) & ++ \\
Kontrol(Asam Sitrat $2 \%$ b/v) & ++ \\
25 & ++ \\
50 & ++ \\
75 & ++ \\
100 & + \\
\hline
\end{tabular}

Keterangan

$+\quad$ : sedikit gula pereduksi

$+\quad$ : banyak gula pereduksi

Level gula pereduksi buah apel kontrol relatif sama dengan buah apel malang perlakuan dengan konsentrasi $25 \% \mathrm{v} / \mathrm{v}, 50 \% \mathrm{v} / \mathrm{v}$, dan $75 \% \mathrm{v} / \mathrm{v}$, namun hanya berbeda pada konsentrasi $100 \% \mathrm{v} / \mathrm{v}$. Hal ini menunjukkan bahwa ekstrak air buah jambu batu dapat meningkatkan level gula pereduksi.

Perbandingkan efek asam sitrat $2 \%$ v/v dengan efek ekstrak air buah jambu batu $25 \%$ v/v terhadap browning. Warna permukaan buah apel malang yang diberi perlakuan asam sitrat $2 \% \mathrm{~b} / \mathrm{v}$ relatif sama dengan buah apel malang yang diberi perlakuan ekstrak air buah jambu batu konsentrasi $25 \% \mathrm{v} / \mathrm{v}$. Sehingga untuk memahami karakteristik ekstrak air buah jambu batu maka peneliti membandingkan efek asam sitrat $2 \%$ v/v dengan efek ekstrak air buah jambu batu $25 \% \mathrm{v} / \mathrm{v}$. Efek asam sitrat $2 \% \mathrm{~b} / \mathrm{v}$ terhadap browning buah apel malang ditunjukan pada Tabel 2. 
Husaini, O dkk : Karakterisasi Bahan Anti Browning dari Ekstrak Air Buah Jambu Batu (Psidium guajava Linn)...

Tabel 2. Efek asam sitrat $2 \% \mathrm{~b} / \mathrm{v}$ terhadap browning buah apel malang

\begin{tabular}{lcc}
\hline \multicolumn{1}{c}{ Variabel } & Efek & Besarnya perubahan \\
\hline Warna permukaan daging buah apel & Relatif lebih & - \\
Indeks browning & putih & $15,8 \%$ \\
Kandungan karbohidrat terlarut total & - & $4,19 \%$ \\
Gula pereduksi & - & - \\
Aktivitas enzim dehidrogenase & $\mathbf{1}$ & $11,40 \%$ \\
\hline
\end{tabular}

Efek ekstrak air buah jambu batu dengan konsentrasi $25 \%$ v/v terhadap browning buah apel malang ditunjukan pada Tabel 3.

Tabel 3. Efek ekstrak air buah jambu batu dengan konsentrasi 25\% v/v terhadap browning buah apel malang

\begin{tabular}{lcc}
\hline \multicolumn{1}{c}{ Variabel } & Efek & Besarnya perubahan \\
\hline Warna permukaan daging buah apel & Relatif lebih & - \\
& putih & $24,37 \%$ \\
Indeks browning & $\mathbf{1}$ & $3,80 \%$ \\
Kandungan karbohidrat terlarut total & - & - \\
Gula pereduksi & $\mathbf{1}$ & $474 \%$ \\
Aktivitas enzim dehidrogenase & $\mathbf{1}$ & \\
\hline
\end{tabular}

Warna permukaan buah apel malang yang diberi perlakuan ekstrak air buah jambu batu dengan konsentrasi $25 \% \mathrm{v} / \mathrm{v}$ menunjukan relatif berwarna putih. Namun, Indeks browning buah apel malang menurunkan sebesar 24,37 \%, Kandungan karbohidrat terlarut total menurunkan sebesar 3,80 \% dan aktivitas enzim dehidrogenase meningkatkan sebesar $474 \%$ yang mengalami perubahan setelah pemberian perlakuan ekstrak air buah jambu batu dengan konsentrasi $25 \% \mathrm{v} / \mathrm{v}$.

Efek asam sitrat $2 \% \mathrm{~b} / \mathrm{v}$ terhadap browning buah apel malang menunjukan bahwa warna permukaan daging buah apel malang dan gula pereduksirelatif sama dengan efek ekstrak air buah jambu batu dengan konsentrasi $25 \%$ v/v. Namun efek ekstrak air buah jambu batu dengan konsentrasi 25\% v/v terhadap indeks browning dan kandungan karbohidrat terlarut total menurunkan lebih besar dibandingkan dengan efek asam sitrat $2 \% \mathrm{~b} / \mathrm{v}$ sedangkan efek ekstrak air buah jambu batu dengan konsentrasi $25 \% \mathrm{v} / \mathrm{v}$ aktivitas enzim dehidrogenase meningkat lebih besar dibandingkan dengan efek asam sitrat $2 \% \mathrm{~b} / \mathrm{v}$.

Menurut hasil penelitian Paramita (2010) buah yang terpotong menyebabkan percepatan respirasi tinggi yang akan merubah proses biokimia diantaranya adalah meningkatnya produksi etilen, pelunakan buah, perkembangan pigmen. Namun, aktivitas metabolisme yang semakin lambat pada kandungan karbohidrat. Dari hasil penelitian menunjukan bahwa pada potongan buah apel malang yang diberi perlakuan ekstrak air buah jambu batu memiliki kandungan karbohidrat yang rendah dibandingkan dengan buah apel malang kontrol. Hal ini akibat dari percepatan respirasi yang tinggi sehingga semakin besar konsentrasi dari ekstrak air buah jambu batu maka semakin relatif rendah kandungan karbohidrat terlarut totalnya.

\section{KESIMPULAN}

Ekstrak air buah jambu batu bersifat anti browning terhadap buah apel Malang dengan efektivitas yang sama dengan asam sitrat $2 \% \mathrm{~b} / \mathrm{v}$. Tetapi memiliki karakteristik yang berbeda dengan asam sitrat $2 \% \mathrm{~b} / \mathrm{v}$ meliputi penurunan indeks browning dan peningkatan enzim dehidrogenase lebih besar dibandingkan asam sitrat $2 \% \mathrm{~b} / \mathrm{v}$. Buah apel malang kontrol dengan buah apel malang yang diberi perlakuan asam sitrat $2 \% \mathrm{~b} / \mathrm{v}$ 
menunjukkan pengaruh indeks browning, kandungan karbohidrat terlarut total dan aktivitas enzim dehidrogenase yang berbeda.

\section{SARAN}

Saran untuk penelitian selanjutnya adalah perlu dilakukan uji organoleptik terhadap ekstrak air buah jambu batu pada buah apel malang dan perlu dibandingkan ekstrak air buah jambu batu dengan senyawa anti browning kimia lainya.

\section{DAFTAR PUSTAKA}

Christin, F., Jeroen Lammertyn, Quang Tri Ho, Pieter Verboven, Bert Verlinden. Bart M. Nicolai. 2007.Browning disorders in pear fruit. Postharvest Biology and Technology. 43(1) : 1-13.

Jeong, H.L., Jin,W.J., Kwang,D.M. and Kee,J.P. 2008.Effect of Anti-Browning Agents on Poyphenoloxidase Activity and Total Phenolics as Related to Browning of Fresh-Cut 'Fuji' Apple. ASEAN Food Journal. 15(1): 79-8.

Paramita, Octavianti. 2010. Pengaruh memar terhadap perubahan pola respirasi, produksi etilen dan jaringan buah mangga (Mangifera indica L.) Var Gedong Gincu pada berbagai suhu penyimpanan.Jurnal Kompetensi Teknik. 2 (1).

Rachmawan, O. 2001. Pengeringan, Pendinginan dan Pengemasan Komoditas Pertanian.Depdiknas. Jakarta.

Sappers, G. M. and R. L. Miller. 1992. Enzymatic browning control in potato with ascorbic acid-2-phosphates. Journal of Food Science. 57(5):1132-1135.

Soelarso, Bambang. 1997.Budi Daya Apel. Yogyakarta : KANISIUS.

Thipnate, Poonsiri and S. Sukhonthara. 2015. Control of Enzymatic Browning in Apple and Potato Purees by Using Guava Extract.Silpakorn U Science \& Tech J Vol.9(2). ISSN 1905-9159.

Witham and Yoshida. 1986. Exercieses in Plant Physiology second Edition ed.Published as: Experiments in Plant Physiology. America. 